\title{
AMK-kirjaston neljännesvuosisadan taival
}

Iris Kuusinen

\begin{abstract}
Ammattikorkeakoulukirjastoja käsittelevä historiikki "Intoa - Tahtoa - Yhteistyötä. Ammattikorkeakoulukirjaston kehitys 1991-2016" on julkaistu. Siinä kuvataan, millaisista lähtökohdista kirjastotoiminta sai alkunsa ja miten kirjastoista on muodostunut nykyaikaisia oppimisympäristöjä. Kirjastolla on ollut merkittävä rooli ammattikorkeakoulun opetuksen laadun kehittämisessä ja korkeakoulustatuksen luomisessa.
\end{abstract}

\section{Koulutuspoliittinen uudistus vauhdittajana}

Vuonna 1991 käynnistyneen ammattikorkeakoulukokeilun yleisenä tavoitteena oli uudistaa opistotasoisten ammatillisten oppilaitosten koulutuksen sisältöä parantamalla opetuksen teoreettista ja ammatillista tasoa. Kirjaston tehtäväksi katsottiin uuden oppimiskulttuurin tukeminen laadukkaiden aineistojen ja tehokkaiden palvelujen avulla. Oppilaitosten kirjastotoiminta sai tämän koulutuspoliittisen uudistuksen johdosta aiempaa suuremman painoarvon.

Suomen ammatillisten oppilaitosten kirjastojen tila oli 1990-luvun alkupuolella yleisesti ottaen heikko eikä kirjastolla ollut selkeää asemaa organisaatiossaan. Ammattikorkeakoulujen tavoitteita ajatellen kirjastojen henkilökunta, kokoelmat ja palvelut olivat vähäiset, harvoja poikkeuksia lukuun ottamatta. Opetusministeriö piti tärkeänä, että ammattikorkeakoulut panostavat kirjasto- ja tietopalvelujen kehittämiseen. Ministeriö vauhditti asiaa erilaisin ohjein, suosituksin ja ehdoin. Yksi merkittävimpiä oli ammattikorkeakoulujen vuosien 1995-2003 tavoite- ja tulossopimuksiin kirjattu velvoite käyttää 3-5 prosenttia käyttömenoistaan kirjastopalveluihin. Ammattikorkeakouluja vakinaistettaessa kirjastopalvelujen toimivuus ja laatu olivat yhtenä arviointikriteerinä.

\section{Intoa ja uudisraivaajahenkeä}

AMK-kirjastojen peruspalvelujen luomiseen tarvittiin paljon työtä ja uudisraivaajahenkeä. Alkuvaiheessa kirjastoja perustettiin miltei jokaiseen ammattikorkeakoulun toimipisteeseen. Samaan hallinnolliseen kirjastokokonaisuuteen saattoi kuulua toistakymmentäkin pienehköä yksikköä. Monin paikoin kirjastoiminta käynnistettiin lähes nollapisteestä hankkimalla tilat, laitteet, kirjastojärjestelmä, kokoelma ja henkilöstö. Tyypillistä oli, että oppilaitoksissa saattoi olla opettajien käytössä isojakin määriä kirjoja, mutta näitä kirjavarantoja ei ollut juurikaan järjestetty ja rekisteröity. Myös asiakaspalvelu- ja lainauskäytänteet puuttuivat joko kokonaan tai olivat hyvin erilaisia saman ammattikorkeakoulun eri oppilaitoskirjastoissakin.

Vaikka AMK-kirjastojen peruspalvelujen ja kokoelman rakentaminen vei alkuvuosina paljon voimavaroja, työ oli myös hyvin innostavaa. Päästiin kehittämään uutta ilman lukkiutuneita tapoja ja vanhoja painolasteja.

\section{Yhteistyöstä potkua}

Kansallinen yhteistyö ja verkostoituminen ovat olleet AMK-kirjastojen kehittämisen voimavara koko toiminnan ajan. Verkostoituminen syntyi voimakkaasta halusta lähteä tekemään asioita yhdessä. Yhteistyön avulla pyrittiin lisäämään kirjastojen vaikutusvaltaa ja toteuttamaan yhtei- 
siä hankkeita. Kirjastojen infrastruktuurin luomisen vuosina 1990-luvulla myös vertaistuki vastaavissa toimintaympäristöissä työskenteleviltä kollegoilta oli kuvainnollisesti sanoen elinehto. Verkostoitumisen merkitys ei ole vuosien saatossa vähentynyt, mitä osoittavat muun muassa tätä historiikkia varten vuonna 2016 tehtyjen kyselyjen ja haastattelujen vastaukset.

Verkostoitumisessa on luonnollisesti ollut merkittävintä AMK-kirjastojen keskinäinen yhteistyö. Alun pitäen Voyager-kirjastojärjestelmän hankintaa varten perustetun Ammattikorkeakoulujen kirjastoyhteistyökonsortion puitteissa on vuosien varrella toteutettu monia hankkeita, joiden tuloksista nyt nautitaan. Yhtenä esimerkkinä mainittakoon Theseus-opinnäytetyökirjasto. Tärkeää AMK-kirjastoille on ollut myös yhteistyö muiden kirjastosektoreiden, Kansalliskirjaston ja Varastokirjaston kanssa. Yhteistyön yliopistokirjastojen suuntaan nähdään vahvistuvan tulevaisuudessa.

\section{Mitä kohden matkataan?}

Ammattikorkeakoulukirjastojen kiihkein rakennusvaihe saatiin päätökseen vuosituhannen vaihteeseen mennessä. Kirjastojen tähänastinen kehityshuippu ajoittuu 2000-luvun alkuvuosiin, jolloin perusinfrastruktuuri oli luotu, toiminta hyvässä vauhdissa ja resursointi korkeimmillaan. Sen jälkeen korkeakoulujen rakennemuutos ja säästöpaineet sekä opetusministeriön kirjastorahoituksen ohjeistuksen poistuminen ovat kääntäneet trendin alenevaksi. Ammattikorkeakoulujen resursointi kirjastoihin on pudonnut alle opetusministeriön 1990-luvulla suosittaman kolmen prosentin minimin.

Rakennemuutoksen seurauksena pienet AMKkirjastot ovat yhdistyneet suuremmiksi kokonai- suuksiksi, mikä on hyvä kehityssuunta. Suuremmat yksiköt mahdollistavat monipuolisemmat palvelut. Huolestuttavaa sen sijaan on, että yhdistymisten kylkiäisenä kirjastojen henkilöstön määrä on vähentynyt kolmanneksella. Henkilöstön määrä oli 2000-luvun alun kehityshuipun aikaankin hyvin maltillinen. Oman haasteensa kehittämiselle luo kirjaston hallinnollisen aseman muutos. Viime vuosina monissa ammattikorkeakouluissa tehdyt organisaatiomuutokset ovat kasvattaneet kirjaston etäisyyttä ylimpään johtoon ja siten välillistäneet vaikutusmahdollisuuksia. Harvalla kirjastonjohtajalla on enää lähiesimiehenä rehtori tai johtoryhmän jäsenyys. AMK-kirjastojen hallinnollinen itsenäisyys vaihtelee ja oma tulosvastuu puuttuu edelleen noin neljäsosalta.

AMK-kirjastot ovat uuden edessä. Suomen korkeakoulujen yhteistyö lisääntyy kaiken aikaa. Kentälle on jo syntynyt yliopistojen ja ammattikorkeakoulujen yhteiskirjastoja ja lisää tullee lähivuosina. Nähtäväksi jää, millaiseksi AMK-kirjastojen toimintaympäristö muodostuu tulevaisuudessa.

\section{Lähde:}

Sirkku Blinnikka ja Iiris Kuusinen. Intoa - Tahtoa Yhteistyötä. Ammattikorkeakoulu-kirjaston kehitys 19912016. AMKIT-konsortio 2017. ISBN 978-952-688832-3 (pdf). http://www.theseus.fi/handle/10024/135702

\section{Tietoa kirjoittajasta:}

FT liris Kuusinen
Kirjasto- ja oppimisteknologiapalvelujen johtaja
Kaakkois-Suomen ammattikorkeakoulussa
2013-2016
Kirjaston johtaja
Kymenlaakson ammattikorkeakoulussa
1996-2013

